\begin{tabular}{|c|c|c|}
\hline \multirow[t]{2}{*}{ BENTHAM OPEN } & The Open Civil Engineering Journal & $\begin{array}{l}\text { The Open } \\
\text { Civil Engine. }\end{array}$ \\
\hline & Content list available at: www.benthamopen.com/TOCIEJ/ & सात्र \\
\hline & DOI: $10.2174 / 1874149501610010323$ & \\
\hline
\end{tabular}

\title{
An Attempt to Reduce Materials Cost of Autoclaved Aerated Concrete Production
}

\author{
Zhijuan Wang, Yuanming Song* and Baoling Li \\ School of Environmental and Materials Engineering, Yantai University, Yantai 264005, People's Republic of China
}

Received: December 27, 2015

Revised: March 6, 2016

Accepted: March 12, 2016

\begin{abstract}
:
Background:

Municipal solid waste incineration (MSWI) bottom ash contains a not insignificant amount of metallic aluminum, while circulating fluidized bed combustion (CFBC) fly ash is rich in active $\mathrm{SiO}_{2}$.
\end{abstract}

\section{Objective:}

To reduce the materials cost of autoclaved aerated concrete (AAC) production, these two types of solid waste could theoretically be used as the aerating agent and silica source, respectively.

\section{Method:}

In the present work, the metallic aluminum concentration in an MSWI bottom ash sample was determined from hydrogen generation and this ash was used to make AAC in conjunction with CFBC fly ash. The extent of air entrainment in the resulting AAC specimens was varied by changing the bottom ash to fly ash ratio, and the effects of this ratio on the properties of the AAC were investigated.

\section{Results:}

Results showed that the ratio has a negligible effect on both the type and the morphology of the hydrates in the AAC, but is inversely proportional to the compressive strength, density and volume stability.

\section{Conclusion:}

This study proves that AAC having satisfactory properties can be successfully prepared from a combination of MSWI bottom ash and CFBC fly ash.

Keywords: Autoclaved aerated concrete, circulating fluidized bed combustion, fly ash, incinerator bottom ash, metallic aluminum, municipal solid waste.

\section{INTRODUCTION}

Municipal solid waste incineration (MSWI) bottom ash contains fewer toxic substances than MSWI fly ash and so has potential construction applications. It has been reported that MSWI bottom ash can be used as a supplementary cementitious material [1 - 3] or as an aggregate in concrete production [4, 5]. It is also known that MSWI bottom ash contains a variable concentration of metallic aluminum [6,7], since household wastes typically contain aluminum products. Autoclaved aerated concrete (AAC) commonly uses aluminum powder as an aerating agent and so MSWI bottom ash could possibly be employed as an aerating agent in AAC production. Our group [8] has previously prepared

\footnotetext{
* Address to correspondence to this author at School of Environmental and Materials Engineering, Yantai University, Qingquan Road, Laishan District, Yantai City, Shandong Province, People's Republic of China; Tel: +86 535 6706335; Fax: +86 535 6706038; E-mail: ytusym@126.com
} 
AAC using MSWI bottom ash as the aerating agent together with ordinary pulverized coal combustion (PCC) fly ash as the siliceous material, producing AAC formulations with density values ranging from 600 to $800 \mathrm{~kg} / \mathrm{m}^{3}$. Because aluminum powder represents about $10 \%$ of the total raw ingredient cost of AAC, the use of MSWI bottom ash as an aerating agent would lower the cost of AAC.

To further reduce the cost of AAC production, employing circulating fluidized bed combustion (CFBC) fly ash as siliceous material could be considered. PCC fly ash has been widely used in construction applications, such that supply often falls short of demand in China, while CFBC fly ash is not as popular. This may be primarily attributed to the disadvantages of CFBC fly ash. For example, although CFBC fly ash contains high levels of active $\mathrm{SiO}_{2}$ and $\mathrm{Al}_{2} \mathrm{O}_{3}$ that are similar to those in PCC fly ash, it also contains an appreciable quantity of unburnt carbon that can lower the waterreducing efficiency when CFBC fly ash is employed as a mineral admixture in concrete. Moreover, CFBC fly ash typically contains high levels of anhydrite, such that its proportion in Portland cement is limited by Chinese national standards [9]. Although CFBC fly ash is thus unfit for use as a supplementary cementitious material in concrete production, it appears that it could potentially be used in AAC production based on several advantages. Firstly, CFBC fly ash is only half the price of PCC fly ash in China. Secondly, dihydrate gypsum is an indispensable constituent of AACs containing PCC fly ash, while AACs containing CFBC fly ash would theoretically not require the addition of dihydrate gypsum, because the properties of anhydrite are similar to those of dihydrate gypsum [10, 11]. It is also helpful that the destructive expansion of the anhydrite in CFBC ash can be effectively controlled by autoclave curing $[12,13]$, and so it appears that CFBC fly ash could be employed for AAC production. This formulation would not only lower the overall cost of the AAC raw materials but would also simplify the production process and so reduce the cost of AAC production.

In addition to cost savings, there is another reason to consider the substitution of CFBC fly ash for PCC fly ash. CFBC technology has the advantages of energy savings and fuel adaptability over PCC technology, and so CFBC boilers have been installed in many countries [14]. The amounts of CFBC fly ash being generated are thus constantly increasing. As a result, PCC fly ash is not always readily available, while in some cases there is an abundant supply of CFBC fly ash. Thus, there are also practical benefits of studying the use of CFBC fly ash in AAC production.

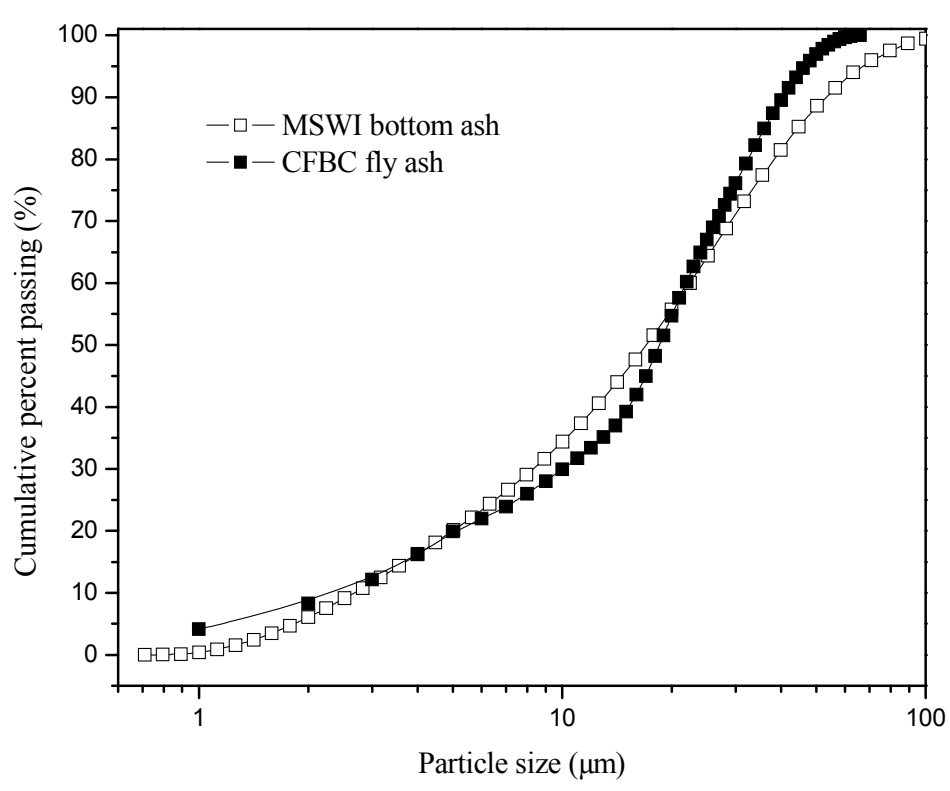

Fig. (1). Size distribution plots for CFBC fly ash and ground MSWI bottom ash.

To our knowledge, few studies have reported AACs produced from MSWI bottom ash and CFBC fly ash. In the present work, we prepared AACs using MSWI bottom ash and CFBC fly ash as the aerating agent and siliceous material, respectively, and studied the properties of the resulting AACs. This work aims to evaluate the feasibility of producing AAC from a combination of MSWI bottom ash with CFBC fly ash. 


\section{MATERIALS AND METHODOLOGY}

\subsection{Materials}

The water-quenched MSWI bottom ash used in this work was oven dried at $105^{\circ} \mathrm{C}$ for $2 \mathrm{~h}$ and then milled for 12 min in a planetary mill (Fritsch PULVERISETTE 5). The CFBC fly ash was used as received. The size gradation curves of the CFBC fly ash and of the ground MSWI bottom ash were obtained using a laser particle size analyzer (Malvern Mastersizer 2000F) and are presented in Fig. (1). It can be seen that the particle size distributions of these two materials were similar.

Table 1 summarizes the average grain size, density and strength activity index (at 28 days) of the two ashes. The MSWI bottom ash had a higher average grain size and density but lower pozzolanic activity as compared with the CFBC fly ash.

Table 1. Physical properties of the CFBC fly ash and ground MSWI bottom ash.

\begin{tabular}{|c|c|c|c|}
\hline Samples & Average grain size $(\boldsymbol{\mu m})$ & Density $\left(\mathbf{g} / \mathbf{c m}^{\mathbf{3}}\right)$ & Strength activity index $\mathbf{~}(\%)$ \\
\hline MSWI bottom ash & 23.2 & 2.78 & 71 \\
\hline CFBC fly ash & 20.0 & 2.47 & 85 \\
\hline
\end{tabular}

${ }^{a}$ Measured in accordance with the chinese standard GB/T17671-1999.

Table 2 presents the chemical compositions of the MSWI bottom ash and CFBC fly ash. The major oxides were $\mathrm{SiO}_{2}, \mathrm{CaO}, \mathrm{Fe}_{2} \mathrm{O}_{3}$ and $\mathrm{Al}_{2} \mathrm{O}_{3}$ in the MSWI bottom ash and $\mathrm{SiO}_{2}$ and $\mathrm{Al}_{2} \mathrm{O}_{3}$ in the CFBC fly ash.

Table 2. Chemical compositions (by mass) of the MSWI bottom ash and CFBC fly ash.

\begin{tabular}{|c|c|c|}
\hline Major oxides content (\%) & MSWI bottom ash & CFBC fly ash \\
\hline $\mathrm{SiO}_{2}$ & 32.75 & 4.98 \\
\hline $\mathrm{CaO}$ & 29.06 & 3.95 \\
\hline $\mathrm{Fe}_{2} \mathrm{O}_{3}$ & 10.02 & 21.69 \\
\hline $\mathrm{Al}_{2} \mathrm{O}_{3}$ & 8.57 & 0.25 \\
\hline $\mathrm{P}_{2} \mathrm{O}_{5}$ & 5.77 \\
\hline $\mathrm{SO}_{3}$ & 3.01 & 0.72 \\
\hline $\mathrm{Na}_{2} \mathrm{O}$ & 1.05 \\
\hline $\mathrm{MgO}_{\mathrm{TiO}}$ & 2.87 & 0.83 \\
\hline $\mathrm{K}_{2} \mathrm{O}$ & 1.75 & 0.51 \\
\hline loss on ignition & 1.57 & 7.46 \\
\hline
\end{tabular}

Fig. (2) provides the X-ray diffraction (XRD) patterns of the CFBC fly ash and MSWI bottom ash. Here it is evident that the main crystalline minerals in the CFBC fly ash were quartz and anhydrite, while the MSWI bottom ash primarily contained quartz and calcite. Metallic aluminum was not detected in the MSWI bottom ash, owing to the very low concentration.

The lime used in this study was obtained by firing analytical grade $\mathrm{CaCO}_{3}$ at $1100{ }^{\circ} \mathrm{C}$ for $2 \mathrm{~h}$, based on a literature procedure [15]. Class PI 52.5 Portland cement was supplied by the Lafarge Cement Factory in Singapore.

\subsection{Methods}

\subsubsection{Determination Of Metallic Aluminum Content In MSWI Bottom Ash}

The principle of gas collection over water was employed to determine the amount of hydrogen generated from MSWI bottom ash, based on a literature procedure [8]. Fig. (3) shows the apparatus used to measure hydrogen volumes. In these trials, $50 \mathrm{~mL}$ of a $1 \mathrm{M} \mathrm{NaOH}$ solution was transferred to a $250-\mathrm{mL}$ three-neck flask and heated to $70{ }^{\circ} \mathrm{C}$ in a water bath, after which approximately $5 \mathrm{~g}$ of ground MSWI bottom ash was added to the flask. Subsequently, the feeder nose was covered and the resulting mixture was agitated to ensure that the ash was uniformly dispersed. Finally, the hydrogen volume at predetermined time points was measured over a span of $60 \mathrm{~min}$. The ambient temperature during these tests was $23^{\circ} \mathrm{C}$. 


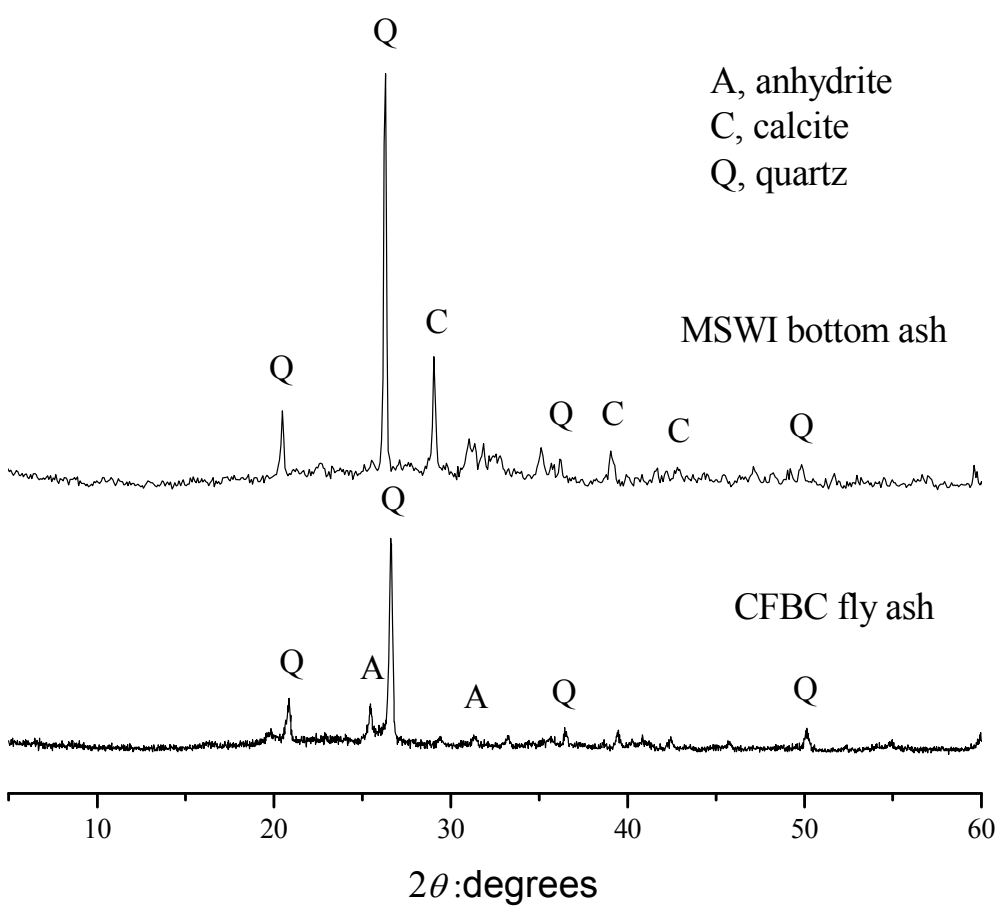

Fig. (2). XRD patterns of the MSWI bottom ash and CFBC fly ash.

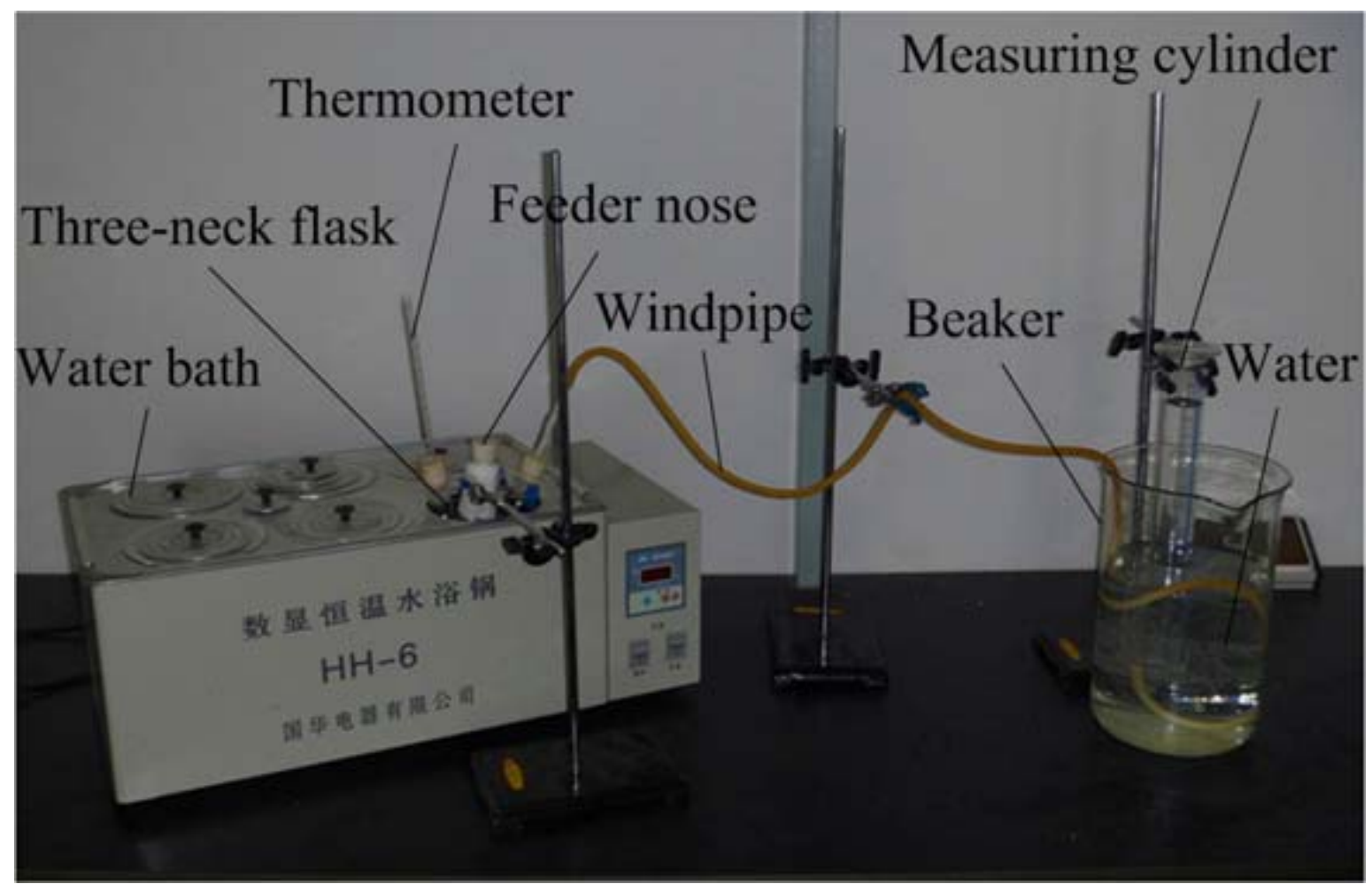

Fig. (3). Apparatus for measuring hydrogen volume. 
It should be noted that the CFBC fly ash used in this study was produced from the combustion of raw coal and so contained almost no metallic aluminum, such that hydrogen was generated solely by the aluminum in the MSWI bottom ash.

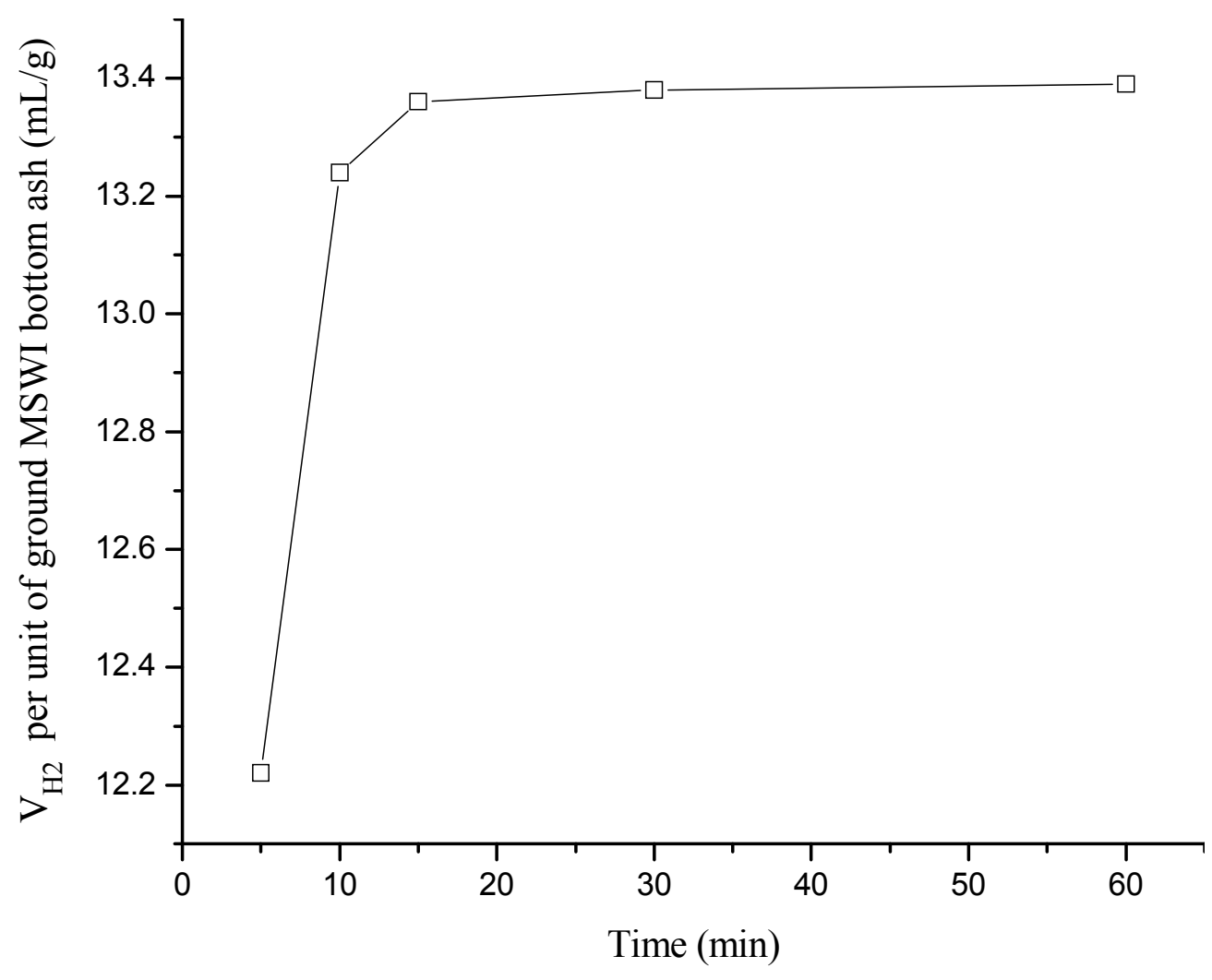

Fig. (4). Hydrogen generation from MSWI bottom ash in a $1 \mathrm{~mol} / \mathrm{L} \mathrm{NaOH}$ solution at $70{ }^{\circ} \mathrm{C}$.

Fig. (4) plots the amount of hydrogen generated from MSWI bottom ash in $1 \mathrm{M} \mathrm{NaOH}$ at $70{ }^{\circ} \mathrm{C}$ as a function of reaction time. The amount of hydrogen increased over time but plateaued at approximately 15 min, revealing that the metallic aluminum in the MSWI bottom ash had reacted entirely with the solution in the first $15 \mathrm{~min}$.

The partial pressure of hydrogen during these trials can be calculated from the following equation:

$\mathrm{p}\left(\mathrm{H}_{2}, 23{ }^{\circ} \mathrm{C}\right)=\mathrm{p}\left(\right.$ atmospheric, $\left.23{ }^{\circ} \mathrm{C}\right)-\mathrm{p}\left(\mathrm{H}_{2} \mathrm{O}, 23{ }^{\circ} \mathrm{C}\right)=101.325 \mathrm{kPa}-2.81 \mathrm{kPa}=98.515 \mathrm{kPa}$

In this manner, it was determined that a total hydrogen volume of $66.80 \mathrm{~mL}$ was obtained from $5.0008 \mathrm{~g}$ of MSWI bottom ash. The corresponding moles of hydrogen $\left(\mathrm{n}\left(\mathrm{H}_{2}\right)\right)$ can be calculated as follows:

$\mathrm{n}\left(\mathrm{H}_{2}\right)=\mathrm{pV} / \mathrm{RT}=98.515 \mathrm{kPa} \times 0.0668 \mathrm{~L} /\left(8.314 \mathrm{kPa} \cdot \mathrm{L} \cdot \mathrm{mol}^{-1} \cdot \mathrm{K}^{-1} \times 296.15 \mathrm{~K}\right)=0.0026727 \mathrm{~mol} \ldots$

The mass of metallic aluminum $(\mathrm{m}(\mathrm{Al}))$ can be obtained from the following reaction and equation.

$2 \mathrm{Al}+2 \mathrm{NaOH}+2 \mathrm{H}_{2} \mathrm{O}=2 \mathrm{NaAlO}_{2}+3 \mathrm{H}_{2} \uparrow \ldots$ (3)

$\mathrm{m}(\mathrm{Al})=(2 / 3) \times \mathrm{n}\left(\mathrm{H}_{2}\right) \times \mathrm{M}_{\mathrm{Al}}=(2 / 3) \times 0.0026727 \mathrm{~mol} \times 27 \mathrm{~g} / \mathrm{mol}=0.0481 \mathrm{~g}$

Finally, the percentage by mass of metallic aluminum in the MSWI bottom ash can be calculated as $0.0481 \mathrm{~g} / 5.0008$ $\mathrm{g} \times 100=0.96 \%$.

Based on the metallic aluminum content in the ash, the aluminum proportions in the AAC formulations provided in Table 3 were $0,0.048,0.096,0.192$ and $0.288 \%$ (by mass), respectively. 


\subsubsection{Sample Preparation}

Table 3 presents the formulations of ACCs containing MSWI bottom ash and CFBC fly ash. The MSWI bottom ash had a lower silica content than the CFBC fly ash (as seen in Table 2) and also contained a significant amount of metallic aluminum (as determined from Fig. (4)). The MSWI bottom ash was thus theoretically suited for use as both an aerating agent and a silica source for the production of AAC, although it was used primarily as the aerating agent in this work. In contrast to common concrete, the properties of AAC are chiefly governed by its porosity, and this will change based on the degree of air entrainment. In addition, the air entrainment can be effectively regulated by changing the proportion of MSWI bottom ash to CFBC fly ash. As stated earlier, the anhydrite in CFBC fly ash can play the same role as dihydrate gypsum and so the AAC need not include dihydrate gypsum.

Table 3. Compositions of ACC specimens (g).

\begin{tabular}{|c|c|c|c|c|c|}
\hline Mix no. & CFBC fly ash & Cement & Lime & MSWI bottom ash & Water \\
\hline AAC0 & 70 & 10 & 20 & 0 & 65 \\
\hline AAC1 & 65 & 10 & 20 & 5 & 65 \\
\hline AAC2 & 60 & 10 & 20 & 10 & 65 \\
\hline AAC3 & 50 & 10 & 20 & 20 & 65 \\
\hline AAC4 & 40 & 10 & 20 & 30 & 65 \\
\hline
\end{tabular}

When producing test samples, a mixture of CFBC fly ash and water was heated to $60{ }^{\circ} \mathrm{C}$ and agitated for 2 min. Cement and lime were then added according to their predetermined proportions and the slurry was stirred for another 2 min. Subsequently, MSWI bottom ash (acting as the aerating agent) was added to the slurry followed by additional stirring for $50 \mathrm{~s}$. The slurry was then poured into stainless steel molds to produce test specimens. Prism-shaped molds with dimensions of 25 by 25 by $280 \mathrm{~mm}$ were used for the drying shrinkage tests while 20 -mm cubic samples were used for all other tests including density, compressive strength and microstructural analysis [8]. Once in the molds, the samples were steam-cured at $60^{\circ} \mathrm{C}$ for $2 \mathrm{~h}$, then removed from the molds and autoclaved at $185^{\circ} \mathrm{C}$ and approximately 1 $\mathrm{MPa}$ for $6 \mathrm{~h}$. Finally, all samples were cured under ambient temperature and pressure for 7 days before testing.

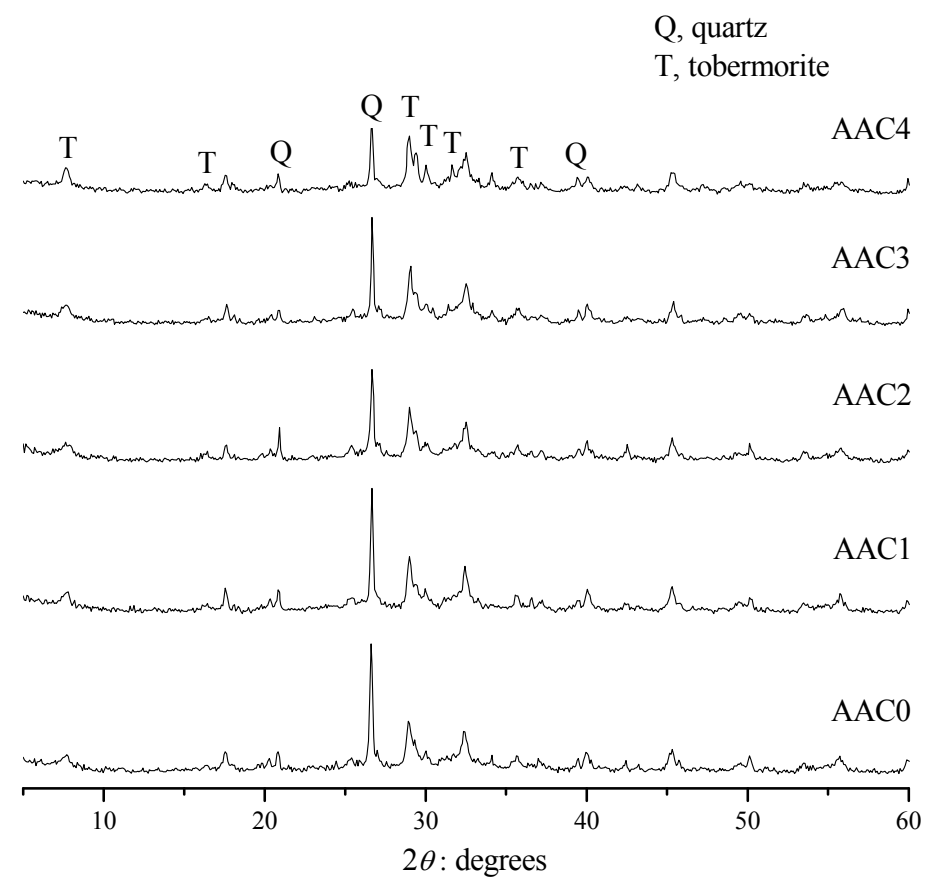

Fig. (5). XRD patterns of ACC specimens.

Microstructure characterization of the AAC hydrates as well as the assessments of density, compressive strength and drying shrinkage were carried out based on previously published procedures $[8,16]$. 


\section{RESULTS AND DISCUSSION}

\subsection{Microstructure Analysis}

Fig. (5) presents the XRD patterns of the AACs produced in this work from MSWI bottom ash and CFBC fly ash. These patterns show that the primary crystalline minerals in the hydrated AACs included tobermorite and quartz. No calcium silicate hydrate (CSH) phase was detected because XRD analysis is ineffective at identifying this type of compound. The diffraction intensity of the quartz in the AACs decreases with increases in the MSWI bottom ash to CFBC fly ash ratio. This may be attributed to the lower $\mathrm{SiO}_{2}$ content of the MSWI bottom ash compared with the CFBC fly ash, as seen in Table 2. Finally, the XRD patterns of the five AACs are seen to be similar, indicating that the ratio had a negligible effect on the hydrates formed.

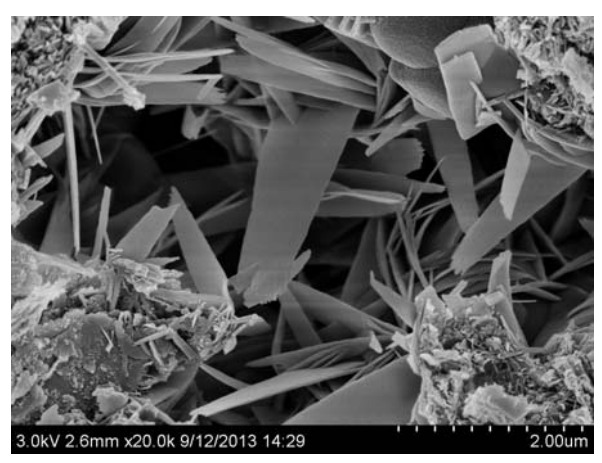

(a) AAC0

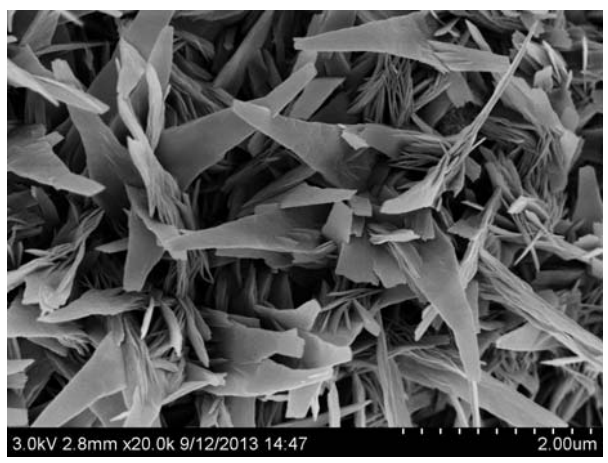

(b) AAC2

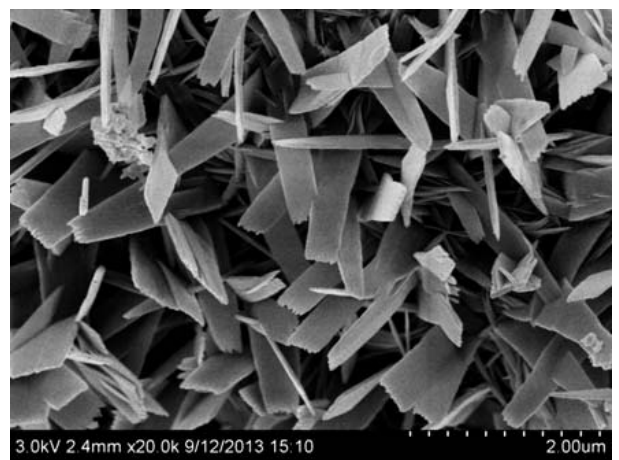

(c) AAC4

Fig. (6). SEM images of ACC0, AAC2 and AAC4 specimens.

Fig. (6) presents scanning electron microscopy (SEM) images of the AAC0, AAC2 and AAC4 samples. Here, it is evident that tobermorite crystals were present in the AACs, and that the MSWI bottom ash to CFBC fly ash ratio had an insignificant effect on the tobermorite size. The MSWI bottom ash tends to generate tobermorite crystals that are both denser and more uniform. This may be attributed to the higher density of the MSWI bottom ash compared with the 
CFBC fly ash, as shown in Table $\mathbf{1 .}$

The reaction between $\mathrm{SiO}_{2}$ and $\mathrm{CaO}$ that generates tobermorite occurs during the hydrothermal processes that take place throughout autoclaving. The MSWI bottom ash contains less $\mathrm{SiO}_{2}$ than the CFBC fly ash (Table 2), so the various AAC samples will consequently have differing $\mathrm{SiO}_{2}$ concentrations; therefore, some changes in the chemical reaction environment during tobermorite generation would be expected. However, our results demonstrate that these changes had a negligible effect on the resulting morphology of the tobermorite.

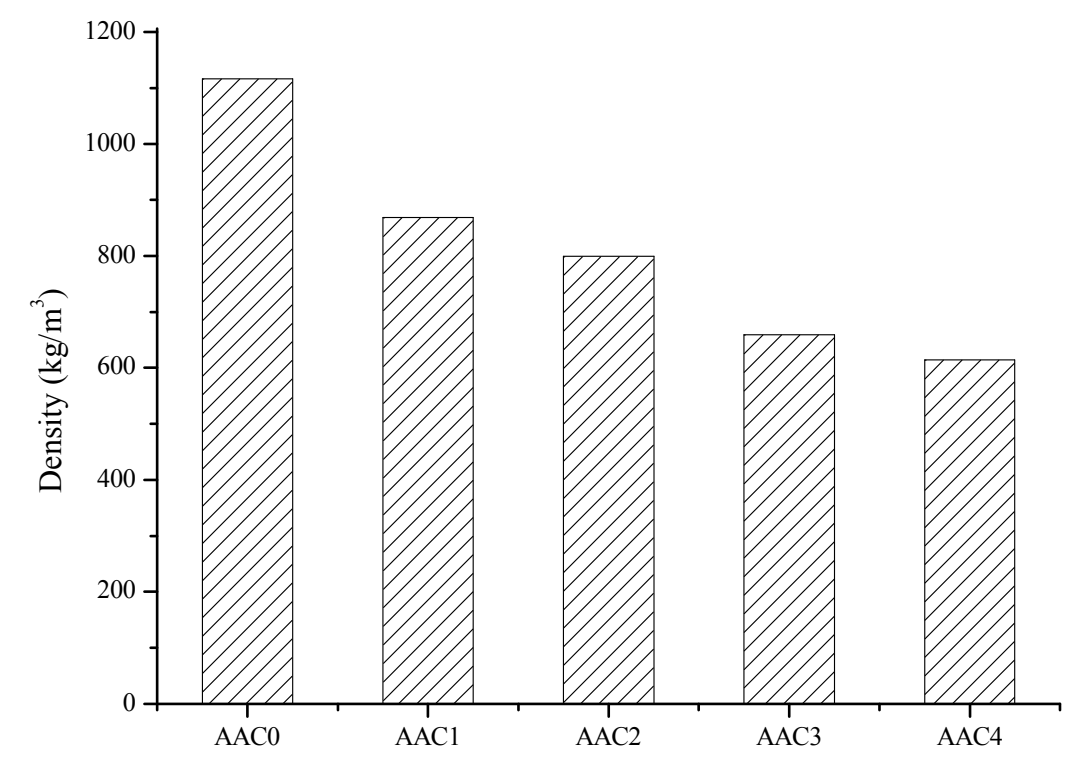

Fig. (7). Density values of AAC samples.

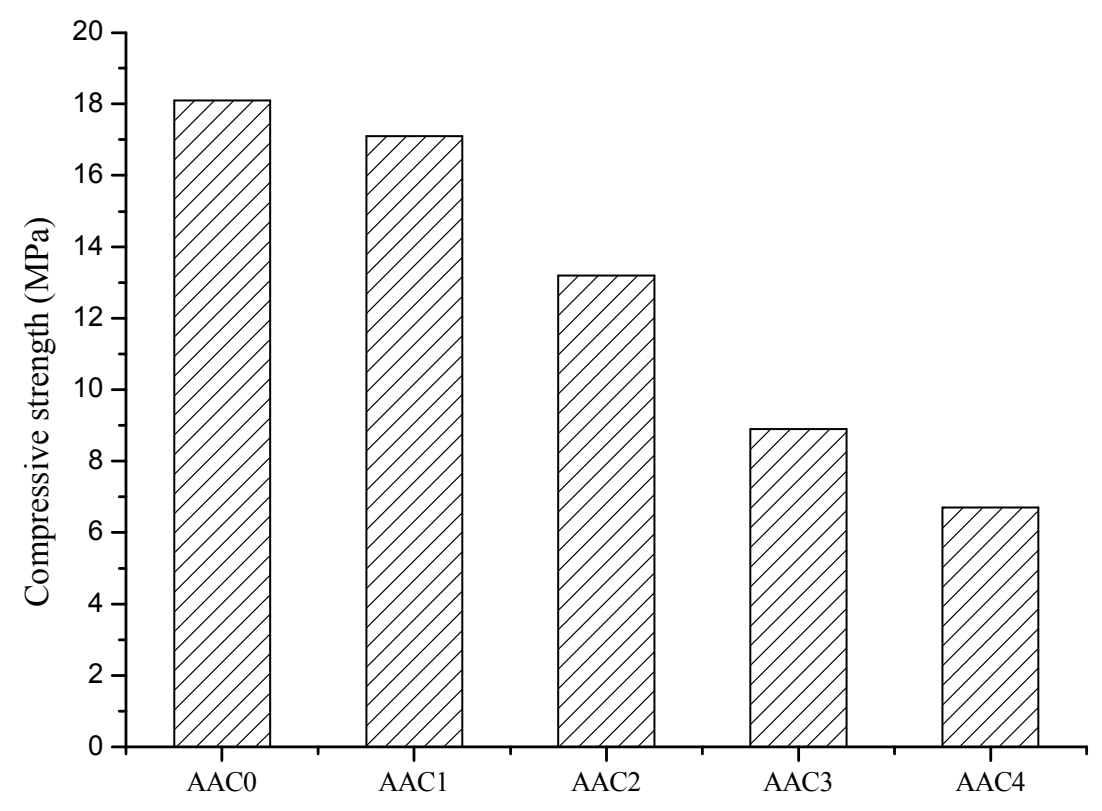

Fig. (8). Compressive strength values of AAC samples.

\subsection{Density}

Fig. (7) summarizes the density values of the AACs, and the density is observed to decrease with increases in the 
MSWI bottom ash to CFBC fly ash ratio. As shown in Table 1, the MSWI bottom ash had a higher density than the CFBC fly ash, and so the trend in Fig. (7) may be primarily attributed to the increasing porosity of the AACs. The metallic aluminum in the AACs also increased with the ratio and so the amount of hydrogen generation was elevated. The density values of samples AAC1 to AAC4 ranged from 869.2 to $614.5 \mathrm{~kg} / \mathrm{m}^{3}$, suggesting that these materials would possess excellent thermal insulation properties.

\subsection{Compressive Strength}

Fig. (8) shows the compressive strengths of the AACs. The strength evidently decreased with increases in the MSWI bottom ash to CFBC fly ash ratio, because compressive strength is closely related to density. The compressive strength of the AACs was thus primarily governed by the porosity of each material; defects commonly increase with increases in porosity and compressive strength thus decreases.

Additionally, compared with AAC containing PCC fly ash [8], AAC containing CFBC fly ash has a significantly higher compressive strength at a given density. This may be attributed to the greater pozzolanic activity of CFBC fly ash $[17,18]$. When formulating AAC, the goal is to minimize the density while still providing sufficient strength, even though strength commonly decreases with decreasing density. That is to say, strength and density are to some extent mutually exclusive properties, such that acceptable compromises between the two are not easily reached. However, it appears that this challenge can be addressed by using CFBC fly ash in AAC production.

\subsection{Drying Shrinkage}

Fig. (9) describes the drying shrinkage of the AAC0, AAC2 and AAC4 specimens. The general trend indicates that drying shrinkage increased with increasing drying time and plateaued at approximately 15 days. The drying shrinkage of the AACs also increased at higher MSWI bottom ash to CFBC fly ash ratios. This effect may be primarily attributed to the increasing porosity of the AACs at higher ratios, because moisture loss on drying is accelerated at elevated ratios. Finally, the strength values of the AACs decreased with increases in the ratio, and so resistance to drying shrinkage was reduced.

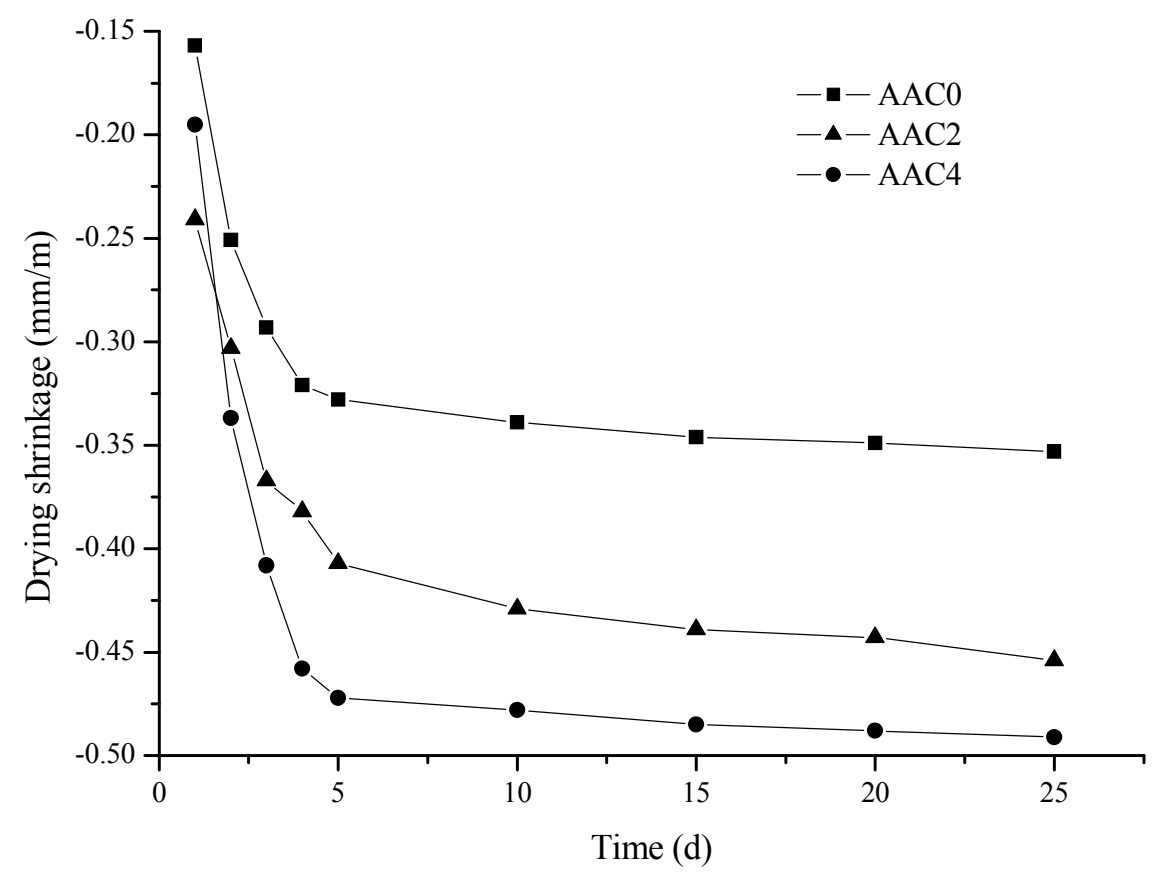

Fig. (9). Drying shrinkage of AAC0, AAC2 and AAC4 specimens.

According to the Chinese national standard, the drying shrinkage of AAC must not exceed $0.50 \mathrm{~mm} / \mathrm{m}$ [16] and the results in Fig. (9) therefore indicate that the AAC specimens exhibited satisfactory volume stability.

From the aforementioned results, it can be concluded that AACs with desirable properties can be successfully 
prepared from a combination of MSWI bottom ash and CFBC fly ash.

The purpose of using AAC is to minimize the density of concrete while still providing the necessary degree of strength [19], and so formulations with density values ranging from 600 to $800 \mathrm{~kg} / \mathrm{m}^{3}$ are more practical with regard to construction applications. Based on this, we propose that the optimum MSWI bottom ash to CFBC fly ash ratio lies in the range of $40 / 30$ to $60 / 10$.

\section{CONCLUSION}

This work assessed the feasibility of producing AAC by combining MSWI bottom ash with CFBC fly ash. Several conclusions can be drawn from the results.

- Firstly, AAC with satisfactory properties can be made using only MSWI bottom ash, CFBC fly ash, cement and lime in the appropriate proportions, even without the additions of dihydrate gypsum and aluminum powder.

- Secondly, the concentration of MSWI bottom ash is inversely proportional to the compressive strength, density and volume stability of the resulting AAC. This may be attributed to the increasing extent of air entrainment with increasing MSWI bottom ash levels.

- Lastly, the optimum ratio of MSWI bottom ash to CFBC fly ash ranges from 40/30 to 60/10.

\section{CONFLICT OF INTEREST}

The authors confirm that this article content has no conflict of interest.

\section{ACKNOWLEDGEMENTS}

The authors wish to acknowledge financial support from the National Natural Science Foundation of China (Grant No. 51272222). They are also grateful to Asst. Prof. Yang En-Hua of the School of Civil and Environmental Engineering, Nanyang Technological University, Singapore, for supplying MSWI bottom ash and for valuable discussions.

\section{REFERENCES}

[1] X. Li, Y. Lv, B. Ma, Q. Chen, X. Yin, and S. Jian, "Utilization of municipal solid waste incineration bottom ash in blended cement", J. Clean. Prod., vol. 32, pp. 96-100, 2012.

[http://dx.doi.org/10.1016/j.jclepro.2012.03.038]

[2] J.R. Pan, C. Huang, J.J. Kuo, and S.H. Lin, "Recycling MSWI bottom and fly ash as raw materials for Portland cement", Waste Manag., vol. 28, no. 7, pp. 1113-1118, 2008.

[http://dx.doi.org/10.1016/j.wasman.2007.04.009] [PMID: 17627805]

[3] H. Shi, and L. Kan, "Characteristics of municipal solid wastes incineration (MSWI) fly ash cement matrices and effect of mineral admixtures on composite systems", Construct. Build. Mater., vol. 23, pp. 2160-2166, 2009. [http://dx.doi.org/10.1016/j.conbuildmat.2008.12.016]

[4] O. Ginés, J.M. Chimenos, A. Vizcarro, J. Formosa, and J.R. Rosell, "Combined use of MSWI bottom ash and fly ash as aggregate in concrete formulation: environmental and mechanical considerations", J. Hazard. Mater., vol. 169, no. 1-3, pp. 643-650, 2009.

[http://dx.doi.org/10.1016/j.jhazmat.2009.03.141] [PMID: 19427118]

[5] O. Hjelmar, J. Holm, and K. Crillesen, "Utilisation of MSWI bottom ash as sub-base in road construction: first results from a large-scale test site", J. Hazard. Mater., vol. 139, no. 3, pp. 471-480, 2007.

[http://dx.doi.org/10.1016/j.jhazmat.2006.02.059] [PMID: 16621249]

[6] J.E. Aubert, B. Husson, and A. Vaquier, "Metallic aluminum in MSWI fly ash: quantification and influence on the properties of cement-based products", Waste Manag., vol. 24, no. 6, pp. 589-596, 2004. [http://dx.doi.org/10.1016/j.wasman.2004.01.005] [PMID: 15219917]

[7] S. Mizutani, S.I. Sakai, and H. Takatsuki, "Investigation of hydrogen generation from municipal solid waste incineration fly ash", J. Mater. Cycles Waste, vol. 2, pp. 16-23, 2000.

[8] Y. Song, B. Li, E. Yang, Y. Liu, and T. Ding, "Feasibility study on utilization of municipal solid waste incineration bottom ash as aerating agent for the production of autoclaved aerated concrete", Cement Concr. Compos., vol. 56, pp. 51-58, 2015.

[http://dx.doi.org/10.1016/j.cemconcomp.2014.11.006]

[9] National Standard of People's Republic of China, Common Portland Cement; GB175-2007, Standard Press of China: Beijing, China, 2007.

[10] A.P. Iribarne, J.V. Iribarne, and E.J. Anthony, "Reactivity of calcium sulfate from FBC systems", Fuel, vol. 76, pp. 321-327, 1997. [http://dx.doi.org/10.1016/S0016-2361(96)00239-6]

[11] Y. Shen, J. Qian, and Z. Zhang, "Investigations of anhydrite in CFBC fly ash as cement retarders", Construct. Build. Mater., vol. 40, pp. 
672-678, 2013.

[http://dx.doi.org/10.1016/j.conbuildmat.2012.11.056]

[12] Y. Song, C. Guo, J. Qian, Z. Wang, and Z. Wang, "Effect of autoclave curing on hydration of anhydrite in CFBC fly ash", Mag. Concr. Res., vol. 67, pp. 1-8, 2015. [http://dx.doi.org/10.1680/macr.14.00117]

[13] B. Wang, and Y. Song, "Methods for the control of volume stability of sulfur-rich CFBC ash cementitious systems", Mag. Concr. Res., vol. 65, pp. 1168-1172, 2013. [http://dx.doi.org/10.1680/macr.13.00070]

[14] G. Sheng, J. Zhai, Q. Li, and F. Li, "Utilization of fly ash coming from a CFBC boiler co-firing coal and petroleum coke in Portland cement", Fuel, vol. 86, pp. 2625-2631, 2007.

[http://dx.doi.org/10.1016/j.fuel.2007.02.018]

[15] N.Y. Mostafa, "Influence of air-cooled slag on physicochemical properties of autoclaved aerated concrete", Cement Concr. Res., vol. 35, pp. 1349-1357, 2005. [http://dx.doi.org/10.1016/j.cemconres.2004.10.011]

[16] National Standard of China, Autoclaved aerated concrete blocks; GB 11968-2006, Standard Administration of China: China, 2006.

[17] G. Sheng, Q. Li, and J. Zhai, "Investigation on the hydration of CFBC fly ash", Fuel, vol. 98, pp. 61-66, 2012. [http://dx.doi.org/10.1016/j.fuel.2012.02.008]

[18] H. Zheng, Z. Wang, J. Qian, Y. Song, and Z. Wang, "Pozzolanic reaction kinetics of coal ashes", J. Wuhan Univ. Technol.- Mater. Sci. Ed., vol. 24, pp. 488-493, 2009.

[19] Y. Song, C. Guo, J. Qian, and T. Ding, "Effect of the Ca-to-Si ratio on the properties of autoclaved aerated concrete containing coal fly ash from circulating fluidized bed combustion boiler", Construct. Build. Mater., vol. 83, pp. 136-142, 2015. [http://dx.doi.org/10.1016/j.conbuildmat.2015.02.077]

(C) Wang et al:; Licensee Bentham Open.

This is an open access article licensed under the terms of the Creative Commons Attribution-Non-Commercial 4.0 International Public License (CC BY-NC 4.0) (https://creativecommons.org/licenses/by-nc/4.0/legalcode), which permits unrestricted, non-commercial use, distribution and reproduction in any medium, provided the work is properly cited. 